\title{
The Effect of Infection by Toxocariasis on Some Biochemical Parameters in Some Areas of Salah Al-Din Governorate
}

\author{
Enas D. Ermeith ${ }^{1}$, Ashraf J. Mahmoud Zangfana ${ }^{1, *}$, Buthaina J. Yousef ${ }^{2}$

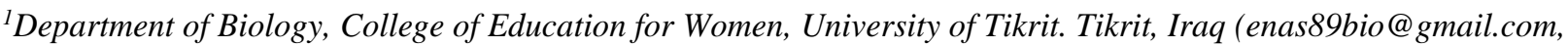 \\ dr.ashraf_bio@tu.edu.iq) \\ ${ }^{2}$ Department of Biology, College of Education for Pure Science, University of Tikrit. Tikrit, Iraq (Buthaina197540@gmail.com) \\ *Correspondence: dr.ashraf_bio@tu.edu.iq
}

\begin{abstract}
The current study examined 277 blood samples of people, from both sexes of different ages, living in different areas of Salah Al-Din Governorate (Tikrit, Al-Alam and Baiji districts). The study was conducted from November, 2018 to June, 2019. All participants were secrened to investigate the incidence of toxocariasis using IgG TES-ELISA technique. The results showed that the rate of infection with toxocariasis was $22 \%$. It was found an increase in cholesterol concentrations within age group $48-58$ years and amounted to 185.8 mg/dl, and highest rate of increase in triglycerides was recorded within age group 15-25 years (168.1 mg/dl). The highest percentage of total protein was recorded within age group 26- 36 years $(6.67 \mathrm{mg} / \mathrm{dl})$. As for lipoprotein tests, highest percentage of high-density lipoproteins in age group 48-58 years was recorded $(53 \mathrm{mg} / \mathrm{dl})$, while low-density lipoproteins were highest in age group 48-58 years (100.8 mg/dl), and in very low-density lipoproteins the highest percentage within age group 15-25 years (33.5 mg/dl). The highest percentage of AST liver enzymes was recorded in age group 15-25 years and the percentage was $20.6 \mathrm{u} / \mathrm{l}$. The highest percentage of ALT was recorded in age group 26-36 years $(20.1 \mathrm{u} / \mathrm{l})$ and $15-25$ years $(20 \mathrm{u} / \mathrm{l})$. It is concluded that This age group continues to be exposed to infection with toxocariasis, which leads to presence large numbers of live larvae which secrete their antigens in the body and thus spread of toxoplasmosis, and the increase in proportion of fats is caused by poor oxidation of fatty acids and increased production of hepatic fatty acids Which leads to a delay in breakdown of lipoproteins, and the increase in level of AST, ALT enzyme occurs in cases of hepatitis and cirrhosis and may be associated with advanced cases of toxocariasis.
\end{abstract}

Keywords: Toxocariasis, T. canis, T. cati, Biochemical Test, Iraq.

Received: October $7^{\text {th }}, 2020 /$ Accepted: November $26^{\text {th }}, 2020 /$ Online: December $20^{\text {th }}, 2020$

\section{INTRODUCTION}

Toxocariasis is one of the most important zoonotic diseases resulting from Toxocara canis (T. canis) and Toxocara cati ( $T$. cati). They are two of the most important nematodes first to find larvae of T. canis in humans (Barriga, 1988). Which accidentally infects humans, especially children, by ingest eggs containing infectious larvae through contaminated soil with dog or cat feces, water and food (Despommier, 2003). These eggs parasitizing small intestine of dogs and cats and other canidae and felines (Radman et al., 2000). Researchers Ransom and Faster in 1920 were the

hatch in front part of small intestine about larvae that penetrate mucosa of intestinal wall and are transported by blood or lymph to visceral organs such as liver, heart, lungs and kidneys cause (VLM) Visceral Larva 
Migrans and sometimes it migrates to eyes, causing (OLM) Ocular Larva Migrans (Saporito et al., 2008).

The life cycle of canine and cat nematodes is complex and includes occasional hosts such as humans, and final host of these worms are dogs and cats. In final host, the worm reaches adult stage and is known as Its behavior is tracheal migration, but in occasional hosts such as humans it is called somatic migration (Tinoco-Gracia et al., 2008; Espinoza et al., 2010).

Early detection of migratory larvae is very difficult in biopsy, and therefore indirect serological tests are considered the best, and at top of these tests comes Enzyme Linked Immunosorbant Assay (ELISA-TEST). ELISA-TEST depends on use of secretory-secretory antigens of second stage larvae of worms. This test is most widely used with high sensitivity and specificity (Jacquier et al., 1991). The current study aimed to diagnose toxocariasis among inhabitants of some areas of Salah Al-Din Governorate using ELISA TEST IgG technique. Also, to study the effect of toxocariasis on some biochemical parameters.

\section{MATERIALS AND METHODS}

\section{A. Epidemiological Study}

The location and duration of study. The current study was conducted in some areas of Salah Al-Din Governorate in each of Tikrit, Baiji and al-Alam cities for period from November, 2018 to June 2019. Information was collected from people according to a questionnaire that included name, gender, age, location of residence, profession. As for collection of 277 blood and serum samples, it was carried out in Baiji General Hospital, Al-Alam Hospital, and private laboratories in Tikrit.

\section{B. Collecting Blood Samples.}

277 Blood samples were collected by withdrawing 4-5 $\mathrm{ml}$ of venous blood using the tourniquet by a medical syringe with a capacity of $5 \mathrm{ml}$. The sample was divided and placed in two types of laboratory tubes. Briefly, $2 \mathrm{ml}$ of the blood sample was added into ready-made tubes that contain anticoagulant for the purpose of completing the blood tests. Then $3 \mathrm{ml}$ of the remaining sample was added to a tube devoid of any substance and left for a period of 10-15 minutes at room temperature for the blood to coagulate. After that, it was placed in a centrifuge for $3500 \mathrm{rpm}$ for the purpose of isolating the serum. Then, it was transferred to the Eppendorf tubes and keept it frozen at a temperature of $-20{ }^{\circ} \mathrm{C}$ until the necessary serological tests are performed on it.

\section{Laboratory Tests}

ELISA test. The test was performed in Central Research Laboratory of Tikrit University, using a test kit provided by Demeditec Company (Germany) with sensitivity $>95 \%$ and specificity $>95 \%$, and following instructions attached to it.

Biochemical tests. Determination of Total cholesterol concentration in serum was performed using a Biolabo Test Kit (France) equipped. Determination of triglycerides in blood serum was performed using a Biolabo Test Kit equipped (Tietz et al.,1999). Determination of Total Protein in serum blood was performed using an AGAPPE Test Kit (India). Determination of High-Density Lipoprotein-cholesterol concentration in serum was performed with a Biolabo (France) Test Kit (Tietz et al.,1999). Estimation of Low-Density lipoprotein-cholesterol (LDL-C) concentration in serum was performed with a Biolab Test Kit (Biolabo,France). Calculation of very Low-Density lipoprotein-cholesterol (VLDL-C) concentration in blood serum: The test was performed with a Biolabo Test Kit. Determination of Aspartate amino transferase (AST) in Blood serum was performed using an AGAPPE Test Kit (India). Determination of alanine amino transferase (ALT) in blood serum was performed using an AGAPPE Test Kit (India).

\section{Statistical Analyses}

The statistical analysis was performed using Chi-square test (X2) and level of significance of differences between rates was estimated by using one way ANOVA followed by Duncan test.

\section{RESULTS}

The results showed that rate of toxocariasis was $22 \%$, and rate of infection was recorded at $23.9 \%$ in both of Tikrit and Baiji district, and $17.9 \%$ to spend knowledge.

The results of tests of the current study showed an increase in levels of cholesterol and triglycerides in serum-positive age groups, which were compared with control group, and results also indicated an increase in rates of total protein and highdensity lipoproteins, as well as in low and very low density lipoproteins (Table 1).

The highest rate of infection was recorded in the cholesterol test within age group 48-58 years, and lowest rate was in age group $37-47$ and 26-36 years, respectively, and in triglyceride examination, highest rate was within age group 15-25 years and lowest rate within group 37-47 years compared to control group. As for total protein test, highest percentage was within age group 26-36 years and lowest percentage was within group 37-47 years. As for lipoprotein tests, as our current study showed an increase in percentages of high-density lipoproteins within age group 48-58 years, and lowest percentage was in 
group 37-47 years and 15-25 years, respectively, and in lowdensity lipoproteins highest percentage was within age group 48-58 years and lowest is within $26-36$ and $15-25$ years respectively (Table 1).

The results of the tests of the current study showed an increase in the rate of AST and ALT enzymes for the serum positive samples of ELISA compared with control group, and statistical analysis showed that there were no significant differences. highest rate of infection was recorded in AST enzyme test as in Table (2) within age group 15-25 years, and lowest percentage was in age group 37-47 and 36-26 years, respectively, and in ALT enzyme test, highest percentage was among 25 age groups. -15 and 26-26 years, respectively, and lowest percentage within age group 48-58 years (Table 2).

Table 1. The relationship between biochemical changes and age in people with toxocariasis in some areas of Salah al-Din Governorate.

\begin{tabular}{|c|c|c|c|c|c|c|c|}
\hline Group & $\begin{array}{l}\text { Age } \\
\text { group }\end{array}$ & $\begin{array}{c}\text { VIDL-C } \\
\mathrm{mg} / \mathrm{dl}\end{array}$ & LDL-C mg/dl & $\begin{array}{c}\text { HDL-Chol } \\
\mathrm{mg} / \mathrm{dl}\end{array}$ & $\begin{array}{c}\text { Total-proten } \\
\mathrm{mg} / \mathrm{dl}\end{array}$ & $\begin{array}{c}\text { Triglyceride } \\
\mathrm{mg} / \mathrm{dl}\end{array}$ & $\begin{array}{c}\text { Cholesterol } \\
\mathrm{mg} / \mathrm{dl}\end{array}$ \\
\hline \multirow{4}{*}{ Infected } & $15-25$ & $\begin{array}{c}33.5 \\
\mathrm{a}\end{array}$ & $\begin{array}{c}93.5 \\
\mathrm{~b}\end{array}$ & $\begin{array}{c}49.1 \\
\mathrm{ab}\end{array}$ & $\begin{array}{c}6.27 \\
\mathrm{a}\end{array}$ & $\begin{array}{c}168.1 \\
\mathrm{a}\end{array}$ & $\begin{array}{c}176.2 \\
b\end{array}$ \\
\hline & $26-36$ & $\begin{array}{c}32.2 \\
\mathrm{ab}\end{array}$ & $\begin{array}{c}92.8 \\
\mathrm{~b}\end{array}$ & $\begin{array}{c}51.5 \\
\mathrm{ab}\end{array}$ & $\begin{array}{c}6.67 \\
\mathrm{a} \\
\end{array}$ & $\begin{array}{c}163.8 \\
\mathrm{ab}\end{array}$ & $\begin{array}{c}177.1 \\
\mathrm{~b}\end{array}$ \\
\hline & $37-47$ & $\begin{array}{c}31.6 \\
a b\end{array}$ & $\begin{array}{c}95.9 \\
\mathrm{~b}\end{array}$ & $\begin{array}{c}48.36 \\
\mathrm{bc}\end{array}$ & $\begin{array}{l}5.8 \\
\mathrm{bc}\end{array}$ & $\begin{array}{c}158.8 \\
\mathrm{~cd}\end{array}$ & $\begin{array}{c}177 \\
\mathrm{~b}\end{array}$ \\
\hline & $48-58$ & $\begin{array}{l}32 \\
a b\end{array}$ & $\begin{array}{c}100.8 \\
\mathrm{a}\end{array}$ & $\begin{array}{c}53 \\
\mathrm{a}\end{array}$ & $\begin{array}{c}6.14 \\
\mathrm{ab}\end{array}$ & $\begin{array}{l}160 \\
b c\end{array}$ & $\begin{array}{c}185.8 \\
\mathrm{a}\end{array}$ \\
\hline \multirow{4}{*}{ Control } & $15-25$ & $\begin{array}{c}32.4 \\
\mathrm{ab}\end{array}$ & $\begin{array}{c}88.5 \\
\mathrm{~cd}\end{array}$ & $\begin{array}{c}45.66 \\
\mathrm{~cd}\end{array}$ & $\begin{array}{l}5.9 \\
\text { bc }\end{array}$ & $\begin{array}{c}153.6 \\
\mathrm{e}\end{array}$ & $\begin{array}{c}165.3 \\
\mathrm{~d}\end{array}$ \\
\hline & $26-36$ & $\begin{array}{c}29.6 \\
\text { bc }\end{array}$ & $\begin{array}{c}86 \\
d\end{array}$ & $\begin{array}{l}45 \\
\mathrm{~cd}\end{array}$ & $\begin{array}{c}6.37 \\
\mathrm{a}\end{array}$ & $\begin{array}{c}155.7 \\
\text { de }\end{array}$ & $\begin{array}{c}174.2 \\
\text { bc }\end{array}$ \\
\hline & $37-47$ & $\begin{array}{c}30.1 \\
\mathrm{bc}\end{array}$ & $\begin{array}{c}91.8 \\
\mathrm{bc}\end{array}$ & $\begin{array}{c}42.5 \\
\mathrm{~d}\end{array}$ & $\begin{array}{c}5.05 \\
d\end{array}$ & $\begin{array}{c}160.4 \\
\mathrm{bc}\end{array}$ & $\begin{array}{c}169.5 \\
\mathrm{~cd}\end{array}$ \\
\hline & $48-58$ & $\begin{array}{c}28.5 \\
\mathrm{c}\end{array}$ & $\begin{array}{c}79.5 \\
\mathrm{e}\end{array}$ & $\begin{array}{l}46 \\
\mathrm{bc}\end{array}$ & $\begin{array}{l}5.3 \\
\mathrm{~cd}\end{array}$ & $\begin{array}{c}152.3 \\
\mathrm{e}\end{array}$ & $\begin{array}{c}174 \\
\mathrm{bc}\end{array}$ \\
\hline
\end{tabular}

(a,b) Small letters indicate to significant differences and large litters indicate no significant differences under level $\mathrm{P} \geq 0.05$

\section{DISCUSSION}

The study was conducted to investigate the prevalence of toxocariasis in some areas of Salah Al-Din Governorate for the period from November to June in Baiji, Tikrit and Al-Alam district.

Several studies have been conducted on dogs infected with toxocariasis, and an increase in levels of cholesterol in their blood serum due to migration of worms into bodies of infected dogs (Muhamed and Al-barwary, 2016; Kumar et al., 2014; Nwoha et al., 2013; Kozan et al., 2010). Low-density lipoproteins have an important role in transporting triglycerides and cholesterol from the liver to muscle and fat tissues (Miles et al.,2005). And that the increase in the percentage of fats is the result of poor fatty acid oxidation and increased hepatic fatty acid synthesis, which leads to delayed breakdown of fatty proteins (Bansal et al.,2005).
Table 2. Relationship between rate of changes in AST and ALT enzymes and age in people infected with toxocariasis in some areas of Salah Al-Din Governorate. a, b, c

\begin{tabular}{|c|c|c|c|}
\hline Group & Age group & $\begin{array}{c}\text { ALT } \\
\mathrm{u} / 1\end{array}$ & $\begin{array}{c}\text { AST } \\
\mathrm{u} / \mathrm{l}\end{array}$ \\
\hline \multirow{3}{*}{ Infected } & $15-25$ & 20 & 20.6 \\
& $26-36$ & $\begin{array}{c}20.1 \\
\mathrm{a}\end{array}$ & $\begin{array}{c}17.1 \\
\mathrm{bc}\end{array}$ \\
\cline { 2 - 4 } & & 18.1 & 16.1 \\
& $37-47$ & $\mathrm{~b}$ & $\mathrm{bc}$ \\
\cline { 2 - 4 } & & 16.6 & 18.7 \\
& $48-58$ & $\mathrm{bc}$ & $\mathrm{b}$ \\
\cline { 2 - 5 } & & $\begin{array}{c}16.1 \\
\mathrm{c}\end{array}$ & $\begin{array}{c}15.1 \\
\mathrm{~cd}\end{array}$ \\
\hline \multirow{6}{*}{ Control } & $15-25$ & 18.4 & 14.4 \\
& & $\mathrm{~b}$ & $\mathrm{~d}$ \\
\cline { 2 - 5 } & $26-36$ & 14.2 & 12.2 \\
& & $\mathrm{~cd}$ & $\mathrm{e}$ \\
\cline { 2 - 5 } & $37-47$ & 13.4 & 13.7 \\
& & $\mathrm{~d}$ & $\mathrm{de}$ \\
\cline { 2 - 5 } & $48-58$ & &
\end{tabular}

The results of our study are consistent with the findings of (Mahmoud, 2014) with regard to cholesterol and triglyceride tests, as an increase in the percentage of tests for serum positive samples compared to the control group was observed. 
The enzyme AST is present in skeletal muscles, heart, liver and is present in other tissues in smaller quantities, and that increase of this enzyme in body is due to breakdown or death of cells in aforementioned organs, which include liver disease, skeletal muscle breakdown and myocardial infarction (Rokni et al., 2000).

As for ALT enzyme, it is present in various tissues, and it is found in abundance and in a greater concentration in liver, and this enzyme is released into blood when it infects liver or becomes infected with other diseases, and thus leads to an increase in its level (Stone, 2005). An increase in this enzyme occurs in cases of hepatitis, poisoning and cirrhosis of liver and may be associated with advanced stages of this disease and malnutrition (Kaneko et al., 1997). The results of this study agree with results of previous studies (Mahmoud, 2014) and (Rokni et al., 2000) in increase in level of enzymes of AST and ALT compared with control group.

\section{V.CONCLUSION}

The highest incidence rates were recorded for the age group 3747 years and $48-58$ years, at $23.94 \%$ and $23.07 \%$, respectively. With an increase in biochemical concentrations, which included cholesterol, triglycerides, lipoproteins, total protein, and the enzyme AST, ALT, in the positive samples for the ELISA test.

\section{REFERENCES}

Barriga, O.O. (1988). A critical look at the importance, prevalence and control of toxocariasis and the possibilities of immunological control. Vet. Parasitol., 29, 195-234.

Bansal,D., Bhatti, H., Sehgal, R. (2005). Roleof cholestrol in parasitic infections. Lipids Health Dis.4:10.

Despommier, D. (2003). Toxocariasis: Clinical aspects , epidemiology , medical ecology and molecular aspects . Clin. Microbial. Rev., 16, 265272.

Espinoza, Y.A., Huapaya, P.H., Roldan, W.H., Jimenez, S., Abanto, E.P., Rojas, C.A., Cavero, Y.A., Gutierrez, C.A. (2010) . Seroprevalence of human toxocariasis in Andean communities from the northeast of Lima. Peru. Rev. Inst. Med. Trop. S. Paulo, 52 (1), $31-36$.

Jacquier, P., Bruno Gottstein, B., Yvonne Stingelin, Y., Eckert, J. (1991). Immunodiagnosis of Toxocarosis in Humans: Evaluation of a New Enzyme-Linked Immunosorbent Assay Kit. Journal of Clinical Microbiology, 29(9), 1831-1835

Kaneko, J.J., Harvey, J.W., Brucs, M.L. (1997). Clinical Biochemistry of Domestic Animals $5^{\text {th }}$ ed. Academic press London. pp.932.

Kozan E., Avc1, G., Sevimli, F.K., Birdane, F.M., Köse, M. (2010). Determine of the antioxidant levels and some biochemical parameters on infected with scaridiosis and treated dogs. Ankara Üniv, Vet. Fak. Derg. 57,93-97.

Kumar, M., Sharma, B., Kumar, A., Lal, H.P., Kumar, V., Tripathi, M.K. (2014). Prevalence and haematobiochemical studies of Toxocara canis infestation in dogs and risk perception of zooneses by dog owners in Mathura, India. Asian J. Anim. Vet. Adv. 9,653-663.

Mahmoud, A.J. (2014). The prevalence of Toxocariasis in Salah Al-Din province with an immune attempt in laboratory mice Balb/c. Thesis, Tikrit Univ., Iraq.
Miles, S.A., Conrad, S.M., Alves, R.G., Jeronimo, S.M., Mosser, D.M.(2005). Arole for IgG immune complexes during infection with theintracellular pathogen Leishmania. J. Exp.Med., 201,747-754.

Muhamed, T.A., Al-barwary, L.T.O. (2016). Prevalence of intestinal parasites in the intestine of dogs (sheep-keeper, owned, pet and stray) in Duhok province, Kurdistan region. J. Vet. Sci. Technol., 7(6), 379-387.

Nwoha, R.I.O., Eze, I.O., Anene, B.M. (2013). Serumbiochemical and liver enzymes changes in dogswith single and conjunct experimental of visceral larva migrans. J. parasitol., 47, 947 - 951.

Radman, N.E., Archelli, S.M., Fonroug, R.D., Guardis, M.V., Linzitto, R.O. (2000). Human toxocariasis. Its seroprevalence in the city of La plata. Memo. do Inst. Oswaldo Cruz., 95, $281-285$.

Rokni, M., Massoud, J., Mowlavi, G. (2000). Reports of 10 cases of visceral larva migrans in Iran. Iran J. Pub. Heal., 29, 61-66.

Saporito, L., Scarlata, F., Colomba, C., Infurnari, L., Giordano, S., Titone, L. (2008). Human toxocariasis: a report of nine cases Acta Paediatr 97, 13011302.

Stone, C. (2005). Med line plus medical encyclopedia. Albumin-serum. A service of the U. S. A. Nat. Lab. Med.

Tietz, N.W., Burtis, E.R., Ashweood, W.B., Saunders, W.B. (1999). Text book of clinical chemistry. $3^{\text {rd }}$ ed., pp:809-857.

Tinoco - Gracia, L., Barreras-Serrano, A., Lopez-Valencia, G., Tamayo-Sosa, A. R., Quiroz-Romero, H., Melgarejo, T. (2008). Seroprevalence of larva migrans of Toxocara canis evalution of associated risk factors among children in a Mexico - united states border region . Int. J. Appl. Res. Vet. Med., 6 (2), 130 - 136. 